\title{
Identification and characterization of domains responsible for self-assembly and cell wall binding of the surface layer protein of Lactobacillus brevis ATCC 8287
}

Silja Åvall-Jääskeläinen ${ }^{\dagger 1}$, Ulla Hynönen ${ }^{\dagger 1}$, Nicola Ilk $^{2}$, Dietmar Pum², Uwe B Sleytr ${ }^{2}$ and Airi Palva*1

\author{
Address: ${ }^{1}$ Department of Basic Veterinary Sciences, Division of Microbiology and Epidemiology, P.O. Box 66, FIN-00014 University of Helsinki, \\ Finland and ${ }^{2}$ Center for NanoBiotechnology, University of Natural Resources and Applied Life Sciences Vienna, A-1180 Vienna, Austria \\ Email: Silja Åvall-Jääskeläinen - silja.avall@helsinki.fi; Ulla Hynönen - ulla.hynonen@helsinki.fi; Nicola Ilk - nicola.ilk@boku.ac.at; \\ Dietmar Pum - dietmar.pum@boku.ac.at; Uwe B Sleytr - uwe.sleytr@boku.ac.at; Airi Palva* - airi.palva@helsinki.fi \\ * Corresponding author †Equal contributors
}

Published: I October 2008

BMC Microbiology 2008, 8:165 doi:10.1186/147I-2180-8-165

This article is available from: http://www.biomedcentral.com/147I-2180/8/165

(C) 2008 Åvall-jääskeläinen et al; licensee BioMed Central Ltd.

This is an Open Access article distributed under the terms of the Creative Commons Attribution License (http://creativecommons.org/licenses/by/2.0), which permits unrestricted use, distribution, and reproduction in any medium, provided the original work is properly cited.

\begin{abstract}
Background: Lactobacillus brevis ATCC 8287 is covered by a regular surface (S-) layer consisting of a 435 amino acid protein SlpA. This protein is completely unrelated in sequence to the previously characterized S-layer proteins of Lactobacillus acidophilus group.

Results: In this work, the self-assembly and cell wall binding domains of SlpA were characterized. The C-terminal self-assembly domain encompassed residues 179-435 of mature SlpA, as demonstrated by the ability of $\mathrm{N}$-terminally truncated recombinant SIpA to form a periodic structure indistinguishable from that formed by full length SlpA. Furthermore, a trypsin degradation analysis indicated the existence of a protease resistant C-terminal domain of 214 amino acids. By producing a set of $\mathrm{C}$-terminally truncated recombinant SlpA ( $\mathrm{rSlpA}$ ) proteins the cell wall binding region was mapped to the $\mathrm{N}$-terminal part of SlpA, where the first 145 amino acids of mature SlpA alone were sufficient for binding to isolated cell wall fragments of $L$. brevis ATCC 8287 . The binding of full length rSlpA to the cell walls was not affected by the treatment of the walls with $5 \%$ trichloroacetic acid (TCA), indicating that cell wall structures other than teichoic acids are involved, a feature not shared by the Lactobacillus acidophilus group S-layer proteins characterized so far. Conserved carbohydrate binding motifs were identified in the positively charged $\mathrm{N}$-terminal regions of six Lactobacillus brevis S-layer proteins.
\end{abstract}

Conclusion: This study identifies SIpA as a two-domain protein in which the order of the functional domains is reversed compared to other characterized Lactobacillus S-layer proteins, and emphasizes the diversity of potential cell wall receptors despite similar carbohydrate binding sequence motifs in Lactobacillus S-layer proteins.

\section{Background}

Surface layers (S-layers) are cell envelope structures ubiquitously found in Gram-positive and Gram-negative bac- terial species as well as in Archaea. They are composed of numerous identical (glyco)protein subunits, 40-200 kDa in molecular weight, which completely cover the cell sur- 
face forming a two-dimensional, regular array having either oblique (p1, p2), square (p4) or hexagonal (p3, p6) symmetry. The subunits are held together and attached to the underlying cell surface by noncovalent interactions, and they have an intrinsic ability to spontaneously form regular layers either in solution or on a solid support under suitable conditions [1]. Functions of S-layers are poorly known thus far. They include the determination and maintenance of cell shape, action as a protective coat, molecular sieve or ion trap or as a mediator of adhesion or surface recognition. The contribution of S-layers to virulence has been reported $[1,2]$.

In general, S-layer proteins have two structural regions in which two essential functions reside: a region involved in the attachment of the S-layer subunit to the cell envelope and a region involved in S-layer assembly. These regions have been characterized in several Gram-positive and some Gram-negative bacteria. In many Gram-positive bacilli and in Thermus thermophilus so called SLH (S-layer homology) motifs [3], 55-60 amino acids long and often located in the N-terminal part of the protein, are responsible for the attachment of the subunit proteins to the cell wall through a pyruvylated polysaccharide receptor in the cell wall [4]. In S-layers of Gram-positive bacteria not having SLH-motifs the attachment to the cell wall has been proposed to be mediated by an interaction between basic amino acids in the cell wall binding region and negatively charged secondary cell wall polymers. The cell wall receptors of such S-layers in Geobacillus species characterized so far contain mannuronic acid and can be classified as acidic oligosaccharides other than teichoic or teichuronic acids, while teichoic and lipoteichoic acids have been shown to be the cell wall receptors of the S-layer proteins of Lactobacillus acidophilus and Lactobacillus crispatus. However, some cell wall polysaccharides of Gram-positive bacteria proposed to be involved in S-layer binding have a net neutral charge $[1,5-7]$.

Among Gram-positive bacteria, the self-assembly regions of S-layer proteins have so far been studied in the S-layers of lactobacilli (see below), and in the S-layers of Bacillus anthracis, Lysinibacillus sphaericus and Geobacillus stearothermophilus. These studies rely on electron microscopy of recombinant S-layer protein fragments, and the selfassembly region has been shown to be of either central or C-terminal location [8-11].

In addition to L. brevis, S-layers have also been found in Lactobacillus helveticus as well as in several Lactobacillus acidophilus group bacteria [12] including L. acidophilus, $L$. crispatus and L. gallinarum. The overall sequence similarity between characterized Lactobacillus S-layer protein genes is low and similarity is usually found only between related species. The presence of multiple S-layer protein genes in a single strain is common in lactobacilli. For example, $L$. brevis ATCC 14869 has three S-layer protein genes, two of which are expressed under different environmental conditions and one is silent under laboratory conditions [13]. Other typical features of Lactobacillus S-layer proteins include their relatively small size and a high predicted overall pI [7]. Self-assembly and cell wall binding regions have been characterized in the S-layer protein $S_{A}$ of Lactobacillus acidophilus ATCC 4356 [14] and CbsA of L. crispatus JCM 5810 [15]. The sequences of $\mathrm{S}_{\mathrm{A}}$ and CbsA are homologous especially in the C-terminal region, which mediates the attachment to the cell wall, and the more variable N-terminal part is responsible for the self-assembly of the S-layer subunits.

The S-layer protein of Lactobacillus brevis ATCC 8287, SlpA [16], is a 435 amino acid, $46 \mathrm{kDa}$ protein, which assembles on the bacterial cell forming an oblique lattice [17] and for which a fibronectin-binding function has been described [18]. L. brevis is phylogenetically distant from $L$. acidophilus group [19], and this is reflected in the unique amino acid sequence of SlpA compared to L. acidophilus group S-layer proteins [7]. Foreign epitopes up to 11 amino acids long have been expressed in SlpA in order to develop tools for mucosal immunization [17]. L. brevis ATCC 8287 would be a suitable strain to be used as a live oral vaccine, as it has a GRAS (Generally Recognized As Safe) status and it has been shown to possess probiotic properties [20]. For vaccine development, as well as for nanobiotechnological applications, for which regularly arranged S-layers are especially well-suited [21,22], knowledge about the structure-function relationships of SlpA, presented in this study, is essential.

In this work, we have characterized the two-domain structure of the S-layer protein SlpA of L. brevis ATCC 8287 with its C-terminal self-assembly and N-terminal cell wall binding domains. Conserved carbohydrate binding motifs were detected in the N-terminal, positively charged regions of six L. brevis S-layer proteins; however, the cell wall receptor of SlpA was found to be different from the receptors of previously characterized Lactobacillus S-layer proteins.

\section{Methods}

\section{Bacterial strains, plasmids and culture conditions}

The strains and plasmids used in this study are listed in Table 1. Lactobacillus brevis ATCC 8287 and Lactobacillus acidophilus ATCC 4356 were grown in MRS (Difco, Detroit, MI, USA) at $37^{\circ} \mathrm{C}$. E. coli strains were grown in Luria-Bertani medium or M9ZB-medium [23] at $37^{\circ} \mathrm{C}$ under aeration. When appropriate, kanamycin, $30 \mu \mathrm{g} / \mathrm{ml}$, was used for E. coli. 
Table I: Strains and plasmids used in this study

\begin{tabular}{|c|c|c|}
\hline Strain or plasmid & Relevant properties ${ }^{\mathrm{a}}$ & Reference or source \\
\hline \multicolumn{3}{|l|}{ Strains } \\
\hline Lactobacillus brevis ATCC 8287 & & ATCC \\
\hline Lactobacillus acidophilus ATCC 4356 & & ATCC \\
\hline Escherichia coli $\mathrm{DH} 5 \alpha \mathrm{F}^{\prime}$ & 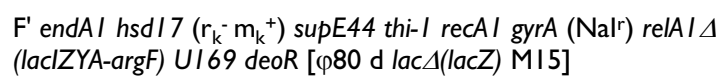 & 58 \\
\hline Escherichia coli BL2I(DE3) & F-ompT hsdS $\left(\mathrm{r}_{\mathrm{B}}^{-} \mathrm{m}_{\mathrm{B}}^{-}\right)$gal dcm (DE3) & Novagen \\
\hline \multicolumn{3}{|l|}{ Plasmids } \\
\hline pET-28a $(+)$ & $\mathrm{Km}^{\mathrm{r}}$, E. coli expression vector & Novagen \\
\hline pET-28b $(+)$ & $\mathrm{Km}^{\mathrm{r}}$, E. coli expression vector & Novagen \\
\hline PKTH5I98 & $\mathrm{Km}^{\mathrm{r}}, \mathrm{pET}-28 \mathrm{~b}(+)\left(\mathrm{Ncol} /\right.$ Xhol::SlpA $_{\mathrm{I}-435}-$-linker $\left._{\text {thrombin }}-\mathrm{Tag}_{\text {his }}\right)$ & This study \\
\hline PKTH5I99 & $\mathrm{Km}^{\mathrm{r}}$, pET-28a(+)(Nhel::Tag ${ }_{\text {his6 }}-$ linker $_{\text {thrombin }}-$ SlpA $\left._{\mid-435}\right)$ & This study \\
\hline PKTH5200 & $\mathrm{Km}^{r}$, pET-28b(+)(Ncol/Xhol::SlpA ${ }_{146-435}$-linker $_{\text {thrombin }}-$ Tag $\left._{\text {his }}\right)$ & This study \\
\hline PKTH520I & $\mathrm{Km}^{\mathrm{r}}$, pET-28b(+)(Ncol/Xhol::SlpA $291-435$-linker ${ }_{\text {thrombin }}-$ Tag $\left._{\text {his }}\right)$ & This study \\
\hline PKTH5203 & $\mathrm{Km}^{\mathrm{r}}$, pET-28a $(+)\left(\right.$ Nhel::Tag his6 -linker $_{\text {thrombin }}-$ SlpA $\left._{\mathrm{I}-145}\right)$ & This study \\
\hline PKTH5204 & 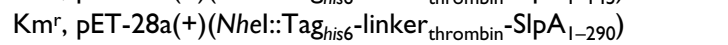 & This study \\
\hline PKTH5258 & $\mathrm{Km}^{\mathrm{r}}$, pET-28a(+)(Nhel::Taghis6 ${ }^{-}$-linker $_{\text {thrombin }}-$ SlpA $\left._{190-423}\right)$ & This study \\
\hline PKTH5259 & $\mathrm{Km}^{\mathrm{r}}$, pET-28a(+)(Nhel::Tag his6 -linker $_{\text {thrombin }}-$ SlpA $\left._{210-423}\right)$ & This study \\
\hline PKTH5260 & 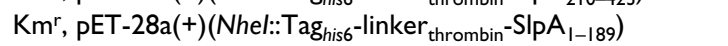 & This study \\
\hline PKTH526I & $\mathrm{Km}^{\mathrm{r}}$, pET-28a(+)(Nhel::Taghis6 ${ }^{-}$-linker $_{\text {thrombin }}-$ SlpA $\left._{190-435}\right)$ & This study \\
\hline PKTH5262 & $\mathrm{Km}^{\mathrm{r}}$, pET-28a(+)(Nhel::Tag his6 -linker $_{\text {thrombin }}-$ SlpA $\left._{210-435}\right)$ & This study \\
\hline PKTH5264 & $\mathrm{Km}^{\mathrm{r}}$, pET-28a(+)(Nhel::Tag his6 -linker $_{\text {thrombin }}-$ SlpA $\left._{167-435}\right)$ & This study \\
\hline PKTH5325 & $\mathrm{Km}_{\mathrm{r}}, \mathrm{pET}-28 \mathrm{a}(+)\left(\right.$ Nhel::Tag $_{\text {his6 }}$-linker $_{\text {thrombin }}-$ SlpA $\left._{179-435}\right)$ & This study \\
\hline PKTH5333 & $\mathrm{Km}_{\mathrm{r}}$, PET-28a $(+)\left(\right.$ Nhel::Tag $_{\text {his6 }}$-linker $_{\text {thrombin }}-$ SlPA $\left._{149-435}\right)$ & This study \\
\hline
\end{tabular}

a $\mathrm{Km}^{\mathrm{r}}$, resistance to kanamycin

\section{DNA manipulations and transformation}

Routine molecular biology techniques were used essentially as described previously [24]. Plasmid DNA of E. coli clones was isolated by using the Wizard Minipreps kit (Promega, Madison, WI, USA). Chromosomal DNA of $L$. brevis was isolated essentially as described before [16]. PCR products were purified with the QIAquick PCR puri- fication kit (Qiagen). DNA restriction and modification enzymes were used as recommended by the manufacturers (New England Biolabs Inc., Beverly, MA, USA; Promega). PCR was carried out with DyNAzyme II DNA polymerase as recommended by the manufacturer (Finnzymes, Helsinki, Finland). E. coli cells were transformed by standard methods [24].

Table 2: Oligonucleotides used in this study.

\begin{tabular}{ll}
\hline Oligonucleotide & Nucleotide sequence $\left(5^{\prime} \rightarrow 3^{\prime}\right)^{\text {a }}$ \\
\hline 1594 & GTCATCCATGGGCAAGTCATACGCTACTGCAGG \\
1595 & TCGCACTCGAGGCTGCCGCGCGGCACCAGGCCGCTGCTGTTGAACCAAGTAGTACCGT \\
1596 & TCGTATCTAGAAATCATACGCTACTGCAGG \\
1597 & TCGCATCTAGATTATTAGTTGAACCAAGTAGTAC \\
1602 & GTCATCCATGGGCCTTTATGGTGTTGCTAAGGAC \\
1603 & GTCATCCATGGGCTCCCAAGCAGCTACTTCTAAG \\
1604 & TCGCACTCGAGGCTGCCGCGC \\
1628 & GTCATGCTAGCAAGTCATACGCTACTGCAGG \\
1629 & ATTCCGCTAGCTTATTAAACAGTAGCGTAAACTGTGTT \\
1630 & TGATAGCTAGCTTATTAGCTAACTTTACTTGCCTTGTAT \\
1635 & ATTCCGCTAGCGGCTTCAGTACTACTGCTACT \\
1636 & TCGCAGCTAGCTTATTAGTTGAACCAAGTAGTAC \\
1637 & ATTCCGCTAGCGTTACAGCAACCAACGATAAC \\
1638 & TGATAGCTAGCTTATTACTTACCAGCGTAAATCC \\
1639 & TGATAGCTAGCTTATTACTTACCCATAACAAGGGT \\
1644 & ACTACGCTAGCGGTTCATTATACTATCACGTAAC \\
1776 & GCGGGCTAGCAGTGGTATTAGTGGTTGGATTT \\
1777 & GCGGGCTAGCGTTGCTAAGGACACCAAGTTT \\
\hline
\end{tabular}

a recognition sites of restriction enzymes are underlined 


\section{Oligonucleotides and DNA sequencing}

Oligonucleotides (Oligomer, Helsinki, Finland) used in this work are listed in Table 2. Nucleotide sequencing was performed by the dideoxy chain termination method of Sanger et al. [25] by using an ABI Prism 310 Genetic analyzer (Applied biosystems, Foster City, CA, USA) in combination with the DNA sequencing kit for BigDye Terminator cycle sequencing (Applied Biosystems).

\section{Protein analysis}

Protein concentrations were determined by Bio-Rad Protein Assay (Bio-Rad, Hercules, CA, USA) using bovine serum albumin as a standard. Protein samples were subjected to sodium dodecyl sulfate-polyacrylamide gel electrophoresis (SDS-PAGE) as described by Laemmli [26] and stained with Coomassie brilliant blue.

\section{Construction of plasmid vectors}

For the expression of the mature SIpA protein, SlpA $\mathrm{A}_{1-435}$ the gene was amplified by PCR from the chromosomal DNA of L. brevis ATCC 8287 using primer pairs 1594/ 1595 or 1596/1597 (Table 2). The PCR fragment obtained with primer pair 1594/1595 was digested with NcoI and Xhol and ligated with NcoI-XhoI digested pET-28b(+), resulting in plasmid pKTH5198 encoding rSlpA with a Cterminal His-tag (Table 1). The PCR product amplified with primers 1596 and 1597 was digested with XbaI and cloned into the NheI site of plasmid pET-28a(+). The resulting plasmid, encoding rSlpA with an $\mathrm{N}$-terminal His-tag, was named pKTH5199.

Three C-terminal truncations, seven N-terminal truncations and two $\mathrm{N}$-and $\mathrm{C}$-terminal truncations of SlpA were constructed, each with a His-tag sequence at either $\mathrm{N}$ - or C-terminus. For a summary of the plasmid constructs, see Table 1. For cloning the C-terminal truncations, primer pairs 1628/1630 (for $\operatorname{SlpA}_{1-145}$ ), 1628/1629 (for $\operatorname{SlpA}_{1-}$ ${ }_{290}$ ) and $1628 / 1638$ (for $\operatorname{SlpA}_{1-189}$ ) (Table 2) were used to amplify the slpA sequences with plasmid pKTH5199 as a template. PCR fragments obtained were digested with NheI and cloned into NheI-digested pET-28a(+). The resulting plasmids were named pKTH5203, pKTH5204 and pKTH5260, respectively (Table 1).

Cloning of the N-terminal truncations of SlpA with the His-tag sequence at the 3 '-terminus was carried out with primer pairs 1602/1604 (for $\operatorname{SlpA}_{146-435}$ ) and 1603/1604 (for SlpA ${ }_{291-435}$ ) (Table 2) and pKTH5198 as a template. The resulting PCR fragments were cloned as NcoI-XhoI fragments into pET-28b(+), giving plasmids pKTH5200 and pKTH5201, respectively (Table 1). For cloning the Nterminal truncations with the His-tag sequence at the 5'-

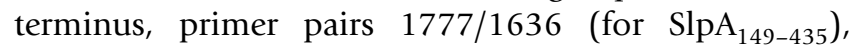
1644/1636 (for $\operatorname{SlpA}_{167-435}$ ), 1776/1636 (for $\operatorname{SlpA}_{179-435}$ ), $1635 / 1636$ (for $\operatorname{SlpA}_{190-435}$ ), or $1637 / 1636$ (for SlpA $A_{210-}$
435) were used to amplify the $\operatorname{sip} A$ sequences with plasmid pKTH5199 as a template. The PCR fragments obtained were digested with NheI and cloned into NheI-digested pET-28a(+) resulting in plasmids pKTH5333, pKTH5264, pKTH5325, pKTH5261 and pKTH5262, respectively (Table 1).

Sequences encoding $\mathrm{N}$-and C-terminally truncated SlpA were PCR amplified with primers 1635/1639 (for SlpA $190-$ 423) and $1637 / 1639$ (for $\operatorname{SlpA}_{210-423}$ ), using plasmid pKTH5199 as a template. The resulting PCR fragments were cloned as NheI-fragments into pET-28a(+), giving plasmids pKTH5258 and pKTH5259, respectively (Table 1 ). All constructs were sequenced to verify the correct open reading frames.

\section{Heterologous expression of the sequences encoding mature SIpA and its truncated forms}

Gene expression was carried out as described in the pET System Manual (Novagen, Madison, WI, USA) by using Escherichia coli strain BL21(DE3). Briefly, expression of recombinant SlpA proteins was induced by adding isopropylthiogalactoside (IPTG) at a concentration of 0.5 to 1.0 $\mathrm{mM}$ to the medium of exponentially growing E. coli strains harboring one of the expression plasmids listed in Table 1. After IPTG was added, the incubation was continued for one to five hours, depending on the protein to be purified. Recombinant SIpA proteins were purified in the presence of $4 \mathrm{M}$ guanidine hydrochloride $(\mathrm{GHCl})$ or $6 \mathrm{M}$ urea with a His Trap HP column according to the instructions given by Amersham Biosciences (Uppsala, Sweden). After purification the fractions containing the recombinant SlpA protein were dialyzed overnight at $+4^{\circ} \mathrm{C}$ against distilled water. Purity of the recombinant proteins, present as a precipitate and/or as soluble proteins after dialysis, was checked by SDS-PAGE.

\section{Isolation of SIPA protein from L. brevis ATCC 8287}

The S-layer protein was extracted from $L$. brevis cells grown to an $\mathrm{OD}_{600 \mathrm{~nm}}$ of 1.0 in MRS broth. Cells from $1 \mathrm{l}$ of culture were harvested and washed twice with distilled water. The pellet was resuspended in $15 \mathrm{ml}$ of $2 \mathrm{M} \mathrm{GHCl}$ and incubated for $30 \mathrm{~min}$ at $+4^{\circ} \mathrm{C}$ followed by centrifugation $(15,000 \times \mathrm{g}$ for $20 \mathrm{~min})$. The supernatant was concentrated with Centricon Plus-20 centrifugal filter (Millipore, Bedford, MA, USA) before dialysis against distilled water supplemented with $5 \mathrm{mM} \mathrm{CaCl}_{2}$ overnight at $+4^{\circ} \mathrm{C}$, followed by dialysis against distilled water overnight at $4^{\circ} \mathrm{C}$. Before dialysis the SIpA protein concentration was adjusted to $1 \mathrm{mg} / \mathrm{ml}$. After dialysis a centrifugation step $(20,000 \times \mathrm{g}$ for $20 \mathrm{~min})$ was performed. The pellet containing the S-layer self-assembly products was resuspended in $25 \mathrm{mM}$ Tris-HCl buffer ( $\mathrm{pH} 8.0$ ). 


\section{Proteolytic degradation of SIPA with trypsin and peptide mapping}

Isolated SlpA at a concentration of $1 \mathrm{mg} / \mathrm{ml}$ was dialyzed against distilled water supplemented with $5 \mathrm{mM} \mathrm{CaCl}_{2}$ overnight followed by a second overnight dialysis against distilled water. The dialysis was followed by a centrifugation step $(16,000 \times \mathrm{g}$ for $30 \mathrm{~min})$. The S-layer monomers, present in the supernatant, were digested with trypsin under the following conditions: $300 \mathrm{ng}$ SlpA protein and $3 \mu \mathrm{g}$ trypsin (Sigma-Aldrich, St. Louis, MO, USA) in 300 $\mu \mathrm{l}$ of $25 \mathrm{mM}$ Tris- $\mathrm{HCl}$ ( $\mathrm{pH} 8.0$ ) for 10 to $30 \mathrm{~min}$ at $37^{\circ} \mathrm{C}$. The reaction was stopped by heating the samples for 10 min at $100^{\circ} \mathrm{C}$ and the samples were subjected to SDSPAGE. N-terminal sequencing was performed by a gaspulsed liquid sequencer as described previously [27] and peptide mapping by a Biflex matrix-assisted laser desorption ionization-time of flight mass spectrometer (BrukerFranzen Analytic, Bremen, Germany) as described by [28].

\section{Investigation of the self-assembly properties of purified truncated S-layer proteins}

To assess the ability of the recombinant S-layer proteins to self-assemble, affinity purified proteins were dissolved in $5 \mathrm{M} \mathrm{GHCl}$ at a concentration of $1 \mathrm{mg} / \mathrm{ml}$ and the solutions were dialyzed against phosphate-buffered saline (PBS) in Slide-A-Lyzer Mini Dialysis Units (Pierce, Rockford, IL, USA) for two hours at $4^{\circ} \mathrm{C}$. Dialysis was followed by a centrifugation step $(16,000 \times \mathrm{g}$ for $30 \mathrm{~min})$ and the formation of a precipitate was checked by SDS-PAGE. For transmission electron microscopy, $1 \mathrm{mg}$ of the purified, lyophilized proteins were dissolved in $1 \mathrm{ml} 5 \mathrm{M} \mathrm{GHCl}$ in $50 \mathrm{mM}$ Tris-HCl buffer (pH 7.2) and the solution was dialyzed against $10 \mathrm{mM} \mathrm{CaCl}_{2}$ in distilled water for $18 \mathrm{~h}$. Samples were transferred onto carbon-coated electron microscope grids rendered hydrophilic by glow discharge, negative stained with 2,5\% uranyl acetate as described previously [29], and electron micrographs were taken with Philips CM 12 transmission electron microscope (Philips Eindhoven, the Netherlands) operated at $80 \mathrm{kV}$ in a low-dose mode. Freeze-etched preparations of $L$. brevis ATCC 8287 cells were prepared as previously described [30], and lattice constants of the S-layer formed by SlpA were determined as described by [31].

\section{Isolation of native cell wall fragments (CWF) from $\mathrm{L}$. brevis ATCC 8287}

L. brevis ATCC 8287 cells were cultivated overnight in 1 l of MRS broth, collected and washed three times with distilled water. Cells were suspended in $30 \mathrm{ml}$ of $2 \mathrm{M} \mathrm{GHCl}$, incubated shaking for 30 minutes at $+4^{\circ} \mathrm{C}$, collected and washed once with $50 \mathrm{mM}$ Tris- $\mathrm{HCl}$ ( $\mathrm{pH} 7.4)$. Cells were disrupted by French Pressure Cell Press (SLM Instruments

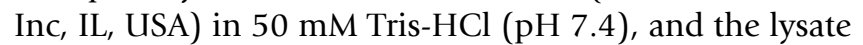
was centrifuged at $3000 \mathrm{~g}$ for 5 minutes at $+4^{\circ} \mathrm{C}$. Cell wall fragments were collected, washed five times with $50 \mathrm{mM}$
Tris-HCl (pH 7.4) and treated with DNAase I $(25 \mu \mathrm{g} / \mathrm{ml}$, Sigma-Aldrich, St. Louis, MO, USA) and RNAase I ( $25 \mu \mathrm{g} /$ $\mathrm{ml}$, Roche Diagnostics GmbH, Mannheim, Germany) in $50 \mathrm{mM}$ Tris- $\mathrm{HCl}$ ( $\mathrm{pH} 7.4$ ), $10 \mathrm{mM} \mathrm{MgCl}_{2}$ for 30 minutes at $37^{\circ} \mathrm{C}$. Cell wall fragments were collected, treated with $1 \%$ SDS for 30 minutes at $100^{\circ} \mathrm{C}$, washed extensively with distilled water at room temperature and lyophilized.

\section{Treatment of native cell wall fragments with TCA}

$0.5 \mathrm{mg}$ or $0.25 \mathrm{mg}$ of isolated CWF in water were incubated in the presence of $5 \%(\mathrm{~V} / \mathrm{V})$ TCA either at $+4^{\circ} \mathrm{C}$ or at $+37^{\circ} \mathrm{C}$ for $24 \mathrm{~h}$ in a rotary shaker. The cell walls were collected, washed three times with distilled water at $+4^{\circ} \mathrm{C}$ and suspended in distilled water. The treatment at $+4^{\circ} \mathrm{C}$ was performed twice. Organic phosphorous was measured from native and treated CWF and from the supernatant obtained in the extraction by the method described by [32].

\section{Binding of the truncated S-layer proteins to bacterial cells and isolated cell wall fragments}

Binding assays of recombinant S-layer proteins to LiClextracted L. brevis ATCC 8287 and L. acidophilus ATCC 4356 cells were performed essentially as described previously [14]. The amount of recombinant S-layer protein used in one binding reaction was $50 \mu \mathrm{g}$ and the buffer was $50 \mathrm{mM}$ Tris- $\mathrm{HCl}$ ( $\mathrm{pH} 7.5$ ) with $150 \mathrm{mM} \mathrm{NaCl}$. The presence of cell-bound S-layer protein in the samples was verified by SDS-PAGE. In binding assays with isolated cell wall fragments, monomeric truncated S-layer proteins, present in the supernatant after centrifugation (20 minutes at $16000 \mathrm{~g}$ at $+4^{\circ} \mathrm{C}$ ), were used. $20 \mu \mathrm{g} \mathrm{CWF}$ and 10 $\mu \mathrm{g}$ full length recombinant SlpA or an equimolar amount of truncated S-layer proteins were combined in $50 \mu \mathrm{l}$ of 50 $\mathrm{mM}$ Tris- $\mathrm{HCl}$ (pH 7.5), $150 \mathrm{mM} \mathrm{NaCl}$. After incubation (1 hour at room temperature) cell wall fragments were collected, washed once with $50 \mathrm{mM}$ Tris- $\mathrm{HCl}$ ( $\mathrm{pH} 7.5), 150$ $\mathrm{mM} \mathrm{NaCl}$, and analyzed by SDS-PAGE.

\section{Analysis of primary amino acid sequences}

The isoelectric point (pI) values of the L. brevis S-layer proteins as well as those of the constructed rSlpA proteins were obtained by ProtParam [33], and the analyses of the hydrophobicity patterns of S-layer proteins of L. brevis were performed by the Kyte-Doolittle method [34] with ProtScale [35] on the ExPASy server. Repeat structures from S-layer proteins were localized by REPRO $[36,37]$. The comparison matrix used in the protein repeat analysis was blosum62 (gap open penalty, 12; gap extension penalty, 1). Sequence alignment analyses of $L$. brevis S-layer proteins were performed by ClustalW [38] using gonnet as a comparison matrix (gap open penalty, 10; gap extension penalty, 0.2). Pairwise comparison analyses were performed by SIM $[39,40]$ using blosum 62 as a comparison matrix (gap open penalty, 12; gap extension penalty, 4). 
From the complete genome sequence of ATCC 367, deposited under GenBank accession number $\mathrm{CP000416}$, the hypothetical S-layer proteins of L. brevis ATCC 367 were identified by BLAST [39] using complete SlpA, SlpB, SlpC and SlpD sequences. The identified hypothetical Slayer proteins of ATCC 367 have been deposited in SwissProt under accession numbers Q03P39 and Q03NT3.

\section{Results \\ Primary amino acid sequence analysis of the S-layer proteins of L. brevis}

The only thus far characterized S-layer proteins in L. brevis are the SlpA protein of L. brevis ATCC 8287 [16] and the SlpB, SlpC and SlpD proteins of L. brevis ATCC 14869 [13]. By performing a homology search for the recently sequenced genome of L. brevis ATCC 367 [41] with the BLAST program, two new putative S-layer proteins, Q03P39 and Q03NT3, were identified in the genome.

The amino acid sequences encoding the mature S-layer proteins of L. brevis ATCC 8287 (SlpA) and ATCC 14869 (SlpB, C and D) and the putative mature S-layer proteins of ATCC 367 (Q03NT3 and Q03P39) were subjected to a number of analyses. A multiple alignment of SlpA, SlpB, SlpC, SlpD, Q03NT3 and Q03P39 amino acid sequences revealed significant conservation in the $\mathrm{N}$-terminal regions (see Fig. 1a and additional file 1: Multiple amino acid sequence alignment of the L. brevis S-layer proteins). Analysis of the distribution of the isoelectric point values in L. brevis S-layer proteins revealed a distinction between the N-terminal region with a high predicted $\mathrm{pI}$ and a Cterminal region with a low predicted $\mathrm{pI}$ in each of the proteins (Fig. 1c). In SlpA and SlpB the region of a high predicted pI comprises approximately two fifths of the protein, while in SlpD and its homolog, Q03P39, as well as in SlpC and its homolog, Q03NT3, the region of an overall high pI extends further towards the C-terminus and the most distinct boundary between the differently charged regions is located around residue 260 in SlpC and Q03NT3 and around residue 290 in SlpD and Q03P39. Hydrophobicity analysis performed for the S-layer protein sequences of $L$. brevis showed a similar distribution of hydrophilic and hydrophobic amino acid residues along the mature proteins with evenly alternating hydrophobic and hydrophilic residues, as exemplified by the hydrophobicity plot of SlpA in Fig. 1b.

To predict the domain organization of SlpA, the analyses performed were compared with similar analyses of the Slayer proteins of $L$. acidophilus group organisms [14]. In each of the L. acidophilus S-layer proteins, one region is found which is conserved, located at the C-terminus and contains positively charged and hydrophilic sequences. In $\mathrm{S}_{\mathrm{A}}$ of L. acidophilus ATCC 4356 and CbsA of L. crispatus JCM 5810 these domains mediate the binding to the cell wall, while the variable $\mathrm{N}$-terminal regions are responsible for the assembly of the S-layer $[14,15]$. In CbsA the variable $\mathrm{N}$-terminal domain is also responsible for collagen binding [42]. The only function characterized for SlpA so far, binding to fibronectin and human epithelial cells [18], resides in the conserved N-terminal region. However, the pattern of sequence conservation and the distribution of charge in the six L. brevis S-layer proteins strongly suggested a domain organization similar to that found in L. acidophilus-group S-layer proteins with the functional domains in a reverse order.

\section{Cloning and expression of gene sequences encoding the mature or truncated forms of the S-layer protein SIPA and purification of the recombinant proteins}

PCR products encoding the mature SlpA and the various $\mathrm{N}$ - or C-terminal SlpA truncations were cloned in E. coli DH5 $\alpha F^{\prime}$ and expressed in E. coli BL21(DE3). The proteins produced are summarized in Fig 2. After induction of expression by the addition of IPTG, samples of cultures from E. coli BL21(DE3) were harvested and analyzed by SDS-PAGE. On SDS-gels, each of the recombinant SlpA proteins became visible as an additional protein band, corresponding approximately to the calculated molecular mass of the rSlpA proteins (data not shown). The proteins were purified in a large scale, and total protein yields varied from 5 to $25 \mathrm{mg}$ per a batch cultivation of $200 \mathrm{ml}$.

\section{Proteolytic degradation of SIPA protein with trypsin and peptide mapping}

To gain insight to the domain structure of SlpA, wild type SlpA was digested with trypsin. This revealed two protease resistant fragments with apparent molecular masses of 25 $\mathrm{kDa}$ and $23 \mathrm{kDa}$ (Fig. 3). The N-terminal sequences of these peptides were determined to be GFSTTAG (larger peptide) and SVTATND (smaller peptide). These correspond to amino acids starting from 190 and 209 of mature SlpA, respectively. Peptide mass mapping of the protease resistant fragments obtained after trypsin digestion revealed that the peptide encompassing the last 12 amino acids of full length SlpA is lacking from these fragments (data not shown). The protease resistance of the regions 190 to 423 and 209 to 423 in mature SlpA strongly suggested the existence of a compact domain structure most likely representing a region exposed on the outer surface of the S-layer.

\section{Investigation of the self-assembly properties of the truncated S-layer protein forms}

As a preliminary test for the putative self-assembly properties of the truncated S-layer proteins, the formation of a precipitate after dialysis from $\mathrm{GHCl}$ was inspected. As shown in Fig. 2, C-terminally truncated proteins $\mathrm{rSlpA}_{1-}$ ${ }_{145}, \mathrm{rSlpA}_{1-189}$ and $\mathrm{rSlpA}_{1-290}$ had lost the ability to form precipitates. N-terminally truncated forms $\mathrm{rSlpA}_{179-435}$ 


\section{(a) $\mathrm{x}$}

(b)

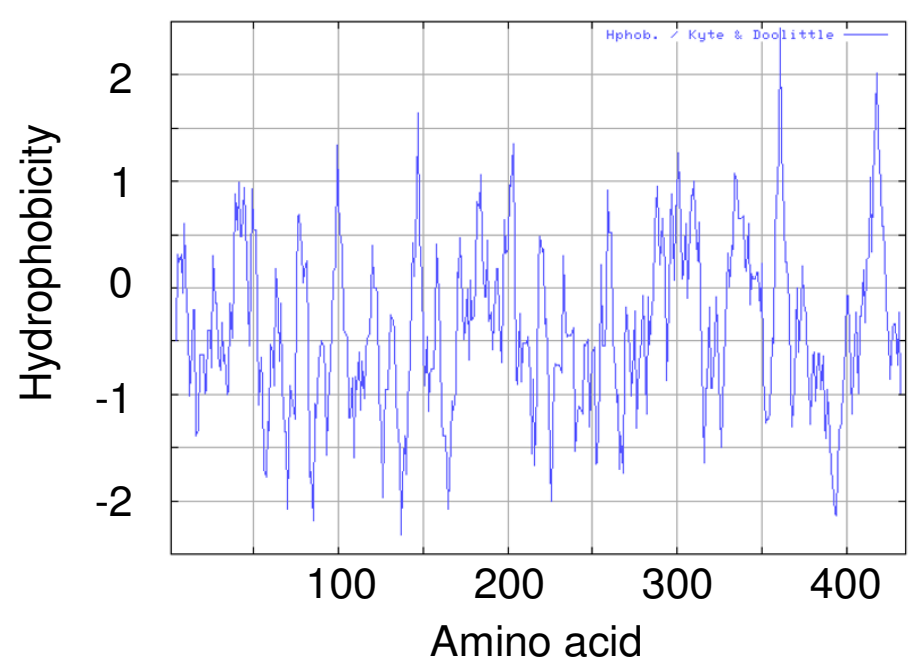

(c)

\begin{tabular}{|l|c|c|}
\hline & \multicolumn{2}{|c|}{ Predicted pl } \\
\hline $\begin{array}{l}\text { SlpA (1-189/ } \\
\text { 190-435) }\end{array}$ & 9.89 & 4.85 \\
\hline $\begin{array}{l}\text { SlpB (1-200/201- } \\
\text { 453) }\end{array}$ & 9.87 & 5.42 \\
\hline $\begin{array}{l}\text { SlpC(1-260/261- } \\
\text { 429) }\end{array}$ & 9.94 & 5.74 \\
\hline $\begin{array}{l}\text { Q03NT3(1- } \\
\text { 260/261-429) }\end{array}$ & 9.89 & 6.07 \\
\hline $\begin{array}{l}\text { SlpD(1-290/291- } \\
\text { 383) }\end{array}$ & 9.80 & 4.88 \\
\hline $\begin{array}{l}\text { Q03P39(1- } \\
\text { 290/291-383) }\end{array}$ & 9.77 & 4.88 \\
\hline
\end{tabular}

Figure I

I (a) - Alignment of $L$. brevis S-layer protein sequences. The mature forms of S-layer proteins were aligned by $C l u s t a l W$ and the alignments were divided into stretches of 10 amino acids, from which the percentage of identical amino acids and amino acids with conserved substitutions were calculated. The following colours are used to indicate the percentages of identical and similar amino acids in each calculated stretch: white, 0-20\%, light gray, $21-40 \%$, medium gray, $4 I-60 \%$, dark gray, $6 \mathrm{I}-$ 80\%. I (b) \&\#82 I I Hydrophobicity of mature SlpA. The hydrophobicity was calculated according to Kyte and Doolittle [34] with a window of seven amino acids. I(c) \&\#82II Predicted pl values of the N-and C-terminal regions of L. brevis S-layer proteins. The lengths of the $\mathrm{N}$ - and $\mathrm{C}$-terminal regions as well as the full lengths of the mature forms of the proteins are indicated in brackets. 


\section{AAs in mature SIpA}

$1-435$
$1-435$
$1-145$
$1-189$
$1-290$
$291-435$
$146-435$
$149-435$
$167-435$
$179-435$
$190-435$
$210-435$
$190-423$
$210-423$

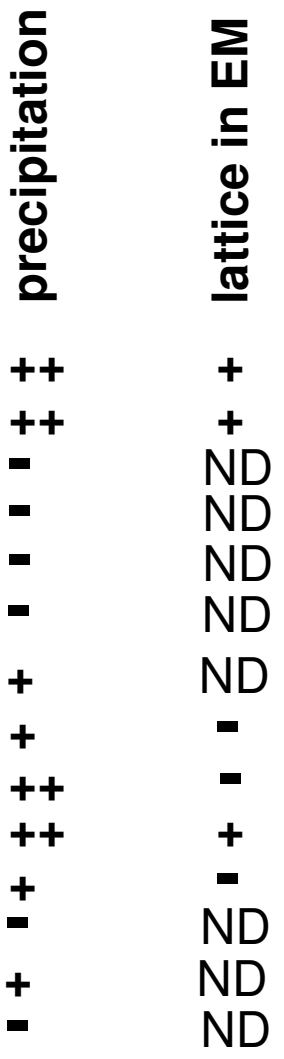

Figure 2

Schematic presentation of the recombinant SIpA proteins expressed and their self-assembly properties. Shaded bars, tags consisting of a I 3 amino acid linker and six histidine residues.

and $\mathrm{rSlpA}_{167-435}$ precipitated efficiently after dialysis, while rSlpA $\mathrm{A}_{146-435}, \mathrm{rSlpA}_{149-435}$ as well as $\mathrm{rSlpA}_{190-435}$ and $\mathrm{rSlpA}_{190-423}$ showed a reduced precipitation. The last twelve residues in the C-terminus of SlpA had no effect on the precipitation, as $\mathrm{rSlpA}_{190-423}$ showed a precipitation similar to $\mathrm{rSlpA}_{190-435}$. The removal of 209 residues or more from the N-terminus of SlpA abolished the ability of the truncated proteins to form precipitates.

Precipitate-forming N-terminally truncated SlpA proteins were chosen for transmission electron microscopical analysis of lattice formation. In these studies, rSlpA formed an oblique lattice that was identical with that formed by SlpA isolated from wild type L. brevis ATCC 8287 cells (compare Figures $4 \mathrm{a}$ and $4 \mathrm{c}$ ), as well as with the lattice seen on L. brevis ATCC 8287 cells in the freeze-etched preparation (Fig. 4d), proving the native conformation of recombinant SlpA. In accordance, lattice constants for the selfassembly products of $\mathrm{rSlpA}(\mathrm{a}=10.38, \mathrm{~b}=6.36$ and $72.7^{\circ}$ ) and for the self-assembly products of SlpA isolated from $L$. brevis ATCC 8287 cells $(\mathrm{a}=9.39, \mathrm{~b}=6.10$ and $\left.79.8^{\circ}\right)$ were practically identical. The recombinant pro- tein $\operatorname{SlpA}_{179-435}$ (Fig. 4b) was found to form a regular, oblique lattice indistinguishable from that formed by full length rSlpA, but the removal of eleven residues more from the N-terminus resulting in $\mathrm{rSlpA}_{190-435}$ prevented lattice formation (Fig. 2). Surprisingly, the two larger Nterminally truncated proteins, $\mathrm{rSlpA}_{167-435}$ and $\mathrm{rSlpA}_{149-}$ 435 , were unable to form regular lattice structures. Thus, residues 179-435 in mature SlpA define the region responsible for the crystallization of SlpA monomers.

\section{Isolation of native cell wall fragments and binding of the truncated S-layer proteins to cell wall fragments}

Cell wall fragments were purified from a stationary phase culture of $L$. brevis cells by differential centrifugation of GHCl-treated, mechanically disrupted cells followed by treatments with nucleases and boiling SDS as described in Materials and methods. This method efficiently removes membrane fragments and noncovalently bound cell wall components like lipoteichoic acids (LTAs), but leaves covalently bound secondary cell wall polymers, like wall teichoic acids and other carbohydrates, essentially intact. The purity of the cell wall preparation was checked by 


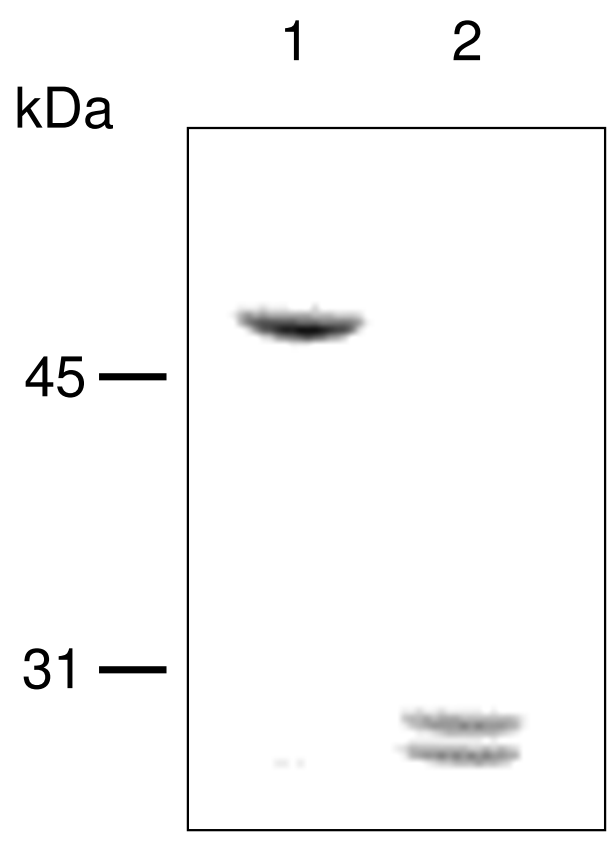

\section{Figure 3}

SDS-PAGE analysis of SIPA fragments obtained after trypsin digestion. Lane I, undigested SIpA. Lane 2, SIpA after digestion with trypsin. Numbers on the left indicate molecular weights in kilodaltons.

light and transmission electron microscopy (Fig. 5). From $1.6 \mathrm{~g}$ of wet cells approximately $28 \mathrm{mg}$ of cell wall fragments (dry weight) were recovered.

To test the hypothesis that the N-terminal, positively charged region of SlpA is responsible for anchoring the Slayer to the cell wall, truncated recombinant SIpA-proteins encompassing the $\mathrm{N}$ - and C-terminal regions of SlpA were tested for binding to isolated $L$. brevis cell wall fragments. As shown in Fig. 6a, full length rSlpA, rSlpA $1-145$ and $\mathrm{rSlpA}_{1-189}$ localized in the pellet fraction after incubation with the cell wall fragments, while $\mathrm{rSlpA}_{190-435}$ and $\mathrm{rSlpA}_{167-435}$ were unable to bind to CWF and were found in the supernatant. Truncated S-layer proteins incubated alone mainly localized to the supernatant, although small amounts were found in the pellets due to the inherent tendency of S-layer proteins to aggregate. These results are in good accordance with our results from similar experiments with whole, LiCl-treated $L$. brevis ATCC 8287 and $L$. acidophilus ATCC 4356 cells. In these experiments, full length rSlpA, rSlpA $\mathrm{A}_{1-145}$ and $\mathrm{rSlpA}_{1-189}$ as well as $\mathrm{rSlpA}_{1-}$ ${ }_{290}$ bound to $L$. brevis cells, while $\mathrm{rSlpA}_{190-435}, \mathrm{rSlpA}_{167-435}$ and $\mathrm{rSlpA}_{210-435}$ were unable to bind. Full-length rSlpA and its cell wall binding fragment $\mathrm{rSlpA}_{1-145}$ also bound to LiCl-treated L. acidophilus ATCC 4356 cells (data not shown).
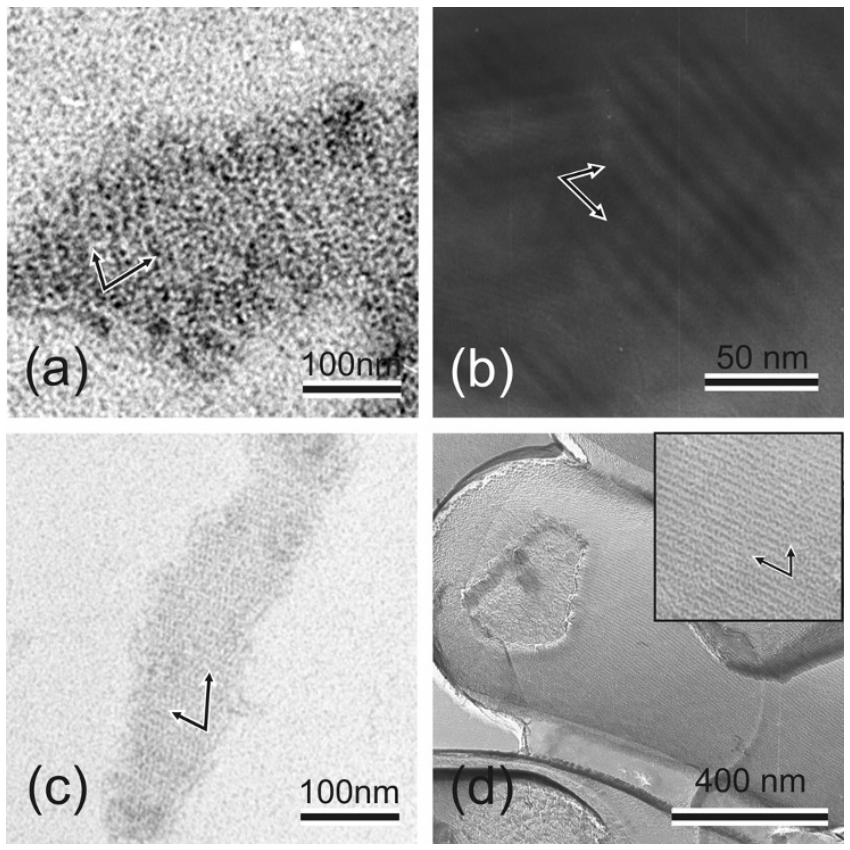

Figure 4

Self-assembly of SIpA, rSIpA and rSIpA C-terminal domain. (a-c) Transmission electron micrographs showing self-assembly products of (a) nontruncated rSlpA, (b) rSlpA $_{179-435}$, and (c) wild type SlpA isolated from $L$. brevis ATCC 8287 cells. (d) Transmission electron micrograph showing a freeze-etched preparation of L. brevis ATCC 8287 cells completely covered with the oblique S-layer lattice formed by SIpA. Arrows indicate the base vectors of the oblique lattice.

To get preliminary information about the cell wall component interacting with the N-terminal region of SlpA, binding tests with full length rSlpA and CWF treated with TCA at $+4^{\circ} \mathrm{C}$ or at $+37^{\circ} \mathrm{C}$ were performed. rSlpA bound to CWF treated with TCA at $+4^{\circ} \mathrm{C}$ as efficiently as to native $\mathrm{CWF}$, while the treatment of CWF with TCA at $+37^{\circ} \mathrm{C}$ substantially reduced the binding of rSlpA (Fig. 6b). Repeated TCA-extraction at $+4{ }^{\circ} \mathrm{C}$ and a change in the rSlpA: CWFratio from $1: 2$ to $1: 1$ did not change the result (data not shown). TCA extracts carbohydrate polymers, and the treatment at $+4^{\circ} \mathrm{C}$ has been reported to selectively remove teichoic acids, while the treatment at $+37^{\circ} \mathrm{C}$ removes teichuronic acids and polysaccharides [43]. The efficiency of the extraction was confirmed by the measurement of organic phosphorous from native and TCA-treated CWF as well as from the supernatant obtained in the extraction, which indicated the loss of approximately $75 \%$ of the organic phosphorous from the CWF by the treatment at $+4{ }^{\circ} \mathrm{C}$ (data not shown). These results suggest that the binding component in the L. brevis ATCC 8287 cell wall is other than teichoic acid, and that cell wall components 


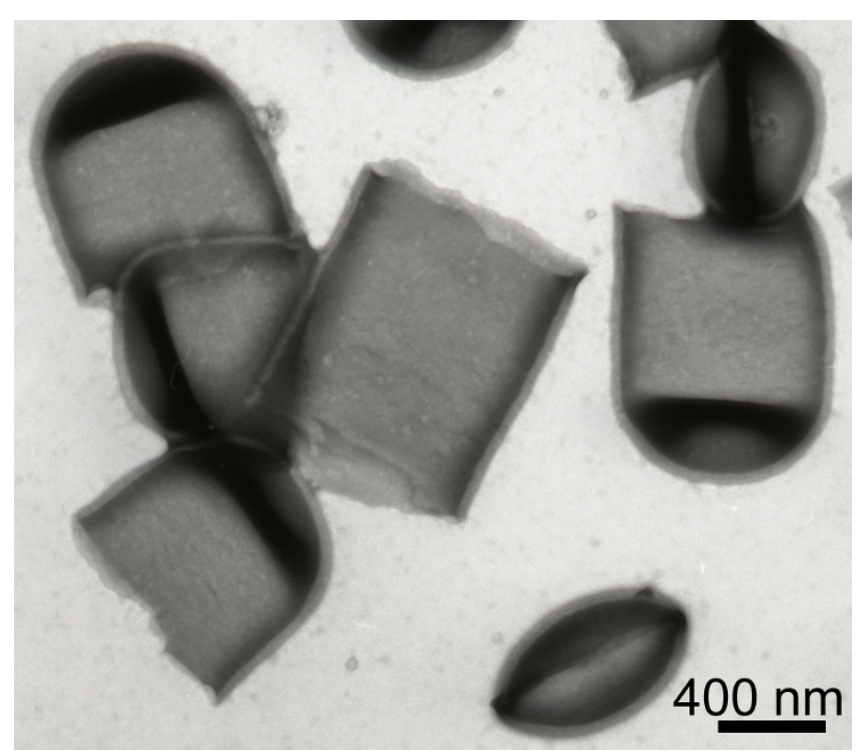

Figure 5

Transmission electron micrograph of isolated native cell walls of $L$. brevis ATCC $\mathbf{8 2 8 7}$.

extractable by TCA at $+37^{\circ} \mathrm{C}$, presumably polysaccharides, participate in the binding.

The amino acid sequence analysis of SlpA and other Lactobacillus brevis S-layer proteins revealed sequences in the $\mathrm{N}$ terminal regions with apparent similarity to the repetitive carbohydrate binding motifs of clostridial toxins and streptococcal glucosyltransferases $[44,45]$. These regions were found within amino acids 60-90 and 165-192 in each of the mature proteins (Fig. 7). In the N-terminal parts of SlpC and Q03NT3 as well as SlpD and Q03P39 additional regions with less obvious similarity were detected as well. Similar motifs have also been detected in the C-terminal cell wall binding regions of $L$. acidophilus ATCC $4356 \mathrm{~S}_{\mathrm{A}}$ protein and L. crispatus JCM 5810 CbsA protein as well as in the S-layer protein of L. helveticus CNRZ 892 and in several other bacterial cell surface-associated proteins, in which they were located in two tandemly repeated sequences of 65-72 amino acids [14]. A protein repeat analysis of the L. brevis S-layer proteins did not indicate the presence of the carbohydrate binding sequences in obvious repeat sequences, and despite the similar carbohydrate binding motifs in SlpA and in L. acidophilus group S-layer proteins, the cell wall receptor of SlpA apparently is dissimilar.

\section{Discussion}

In this study, we have identified the cell wall binding and self-assembly domains in the S-layer protein SlpA of $L$. brevis ATCC 8287 , a strain phylogenetically distant from $L$. acidophilus group organisms, the S-layer proteins of which have previously been functionally characterized. Two new putative S-layer proteins, Q03P39 and Q03NT3, were identified in the recently sequenced genome of $L$. brevis ATCC 367 [41] and compared with SlpA and other L. brevis S-layer proteins characterized thus far. Q03P39 is almost identical (99\% identity) with SlpD of L. brevis ATCC 14869 and relatively dissimilar ( $<40 \%$ identity) from the SlpA, SlpB and SlpC sequences. Q03NT3 is highly similar with SlpC of L. brevis ATCC 14869 (87\% identity) whereas not that similar with the other characterized L. brevis S-layer proteins ( $<44 \%$ identity). Similarity of the mature forms of the new putative S-layer proteins or the mature forms of SlpA, SlpB, SlpC or SlpD proteins with $L$. acidophilus group S-layer proteins is negligible.

Analysis of the six L. brevis S-layer protein sequences deposited in databanks indicated the subdivision of each sequence into two regions: a conserved $\mathrm{N}$-terminal region characterized by a high predicted pI and potential carbohydrate binding motifs, and a more variable C-terminal region with an acidic predicted $\mathrm{pI}$, with the $\mathrm{N}$-terminal region corresponding for $40-75 \%$ of the sequence lengths. The observed high predicted overall $\mathrm{pI}$ values of Lactobacillus S-layer proteins [7] thus seem to be due to the concentration of basic amino acids to a defined region, as is also the case in the S-layer proteins of L. acidophilus group, which have cationic, cell wall binding C-terminal regions.

The presence of a conserved $\mathrm{N}$-terminal region with a high predicted $\mathrm{pI}$ in L. brevis S-layer proteins strongly suggested an N-terminal cell wall binding domain. This was confirmed for SlpA of $L$. brevis ATCC 8287 by interaction studies performed with truncated rSlpA proteins and $\mathrm{LiCl}$ treated $L$. brevis cells or isolated $L$. brevis cell wall fragments. In these studies, truncated proteins encompassing the whole positively charged region of SlpA bound to the cell wall; however, the first 145 residues in mature SlpA contained sufficient information for cell wall binding. An assay suitable for measuring the binding strength would be needed to detect the putative difference between the cell wall binding affinities of SlpA $A_{1-145}$ and $S \operatorname{SlpA}_{1-189}$. In Slayer proteins of lactobacilli, no SLH motifs have been detected. Instead, interactions between a positively charged S-layer protein region and negatively charged secondary cell wall polymers have been shown to mediate the cell wall binding in the case of $\mathrm{S}_{\mathrm{A}}$ of $L$. acidophilus ATCC 4356 [46] and CbsA of L. crispatus JCM 5810 [41]. $\mathrm{S}_{\mathrm{A}}$ and CbsA were shown to bind teichoic acids, and CbsA bound also to lipoteichoic acids purified from Staphylococcus aureus and Streptococcus faecalis, but not to the teichuronic acid/polysaccharide fraction of the cell wall of $L$. crispatus JCM 5810. In contrast, the results of this study suggest the involvement of another cell wall structure 

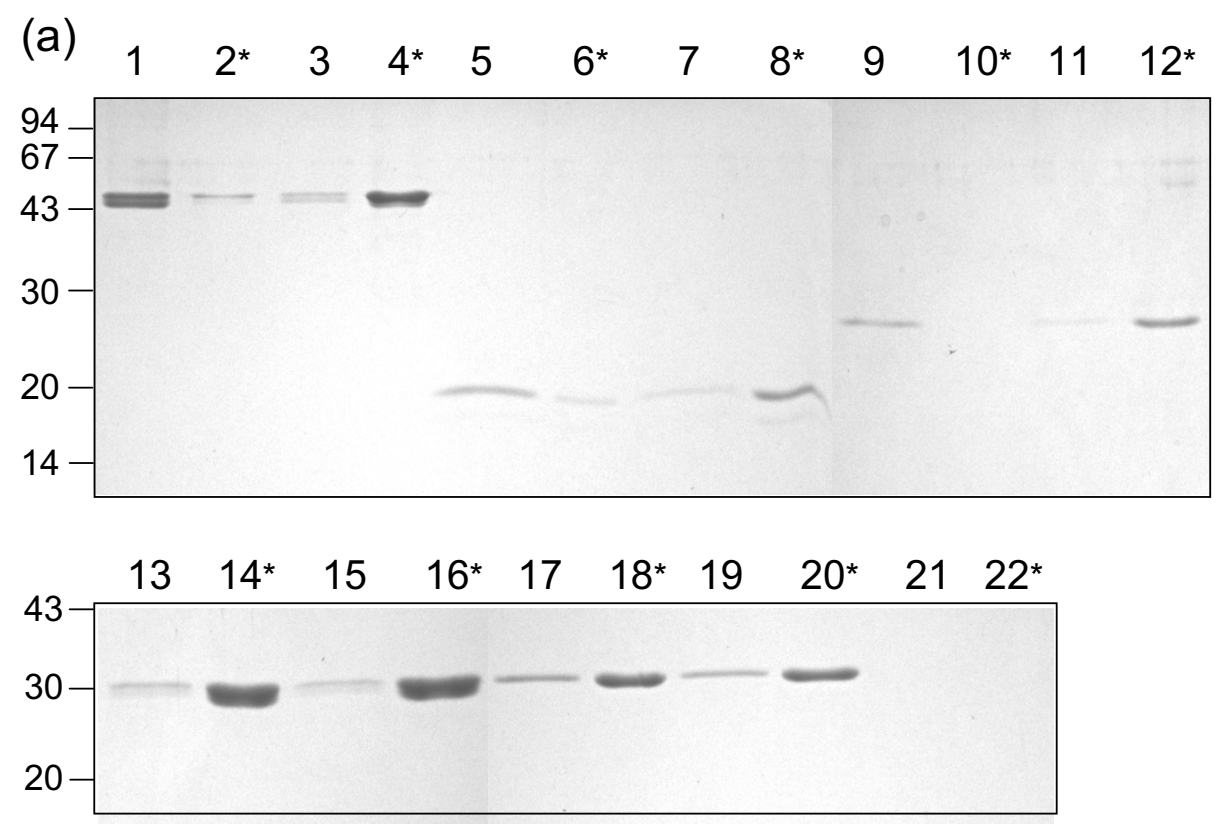

(b1)

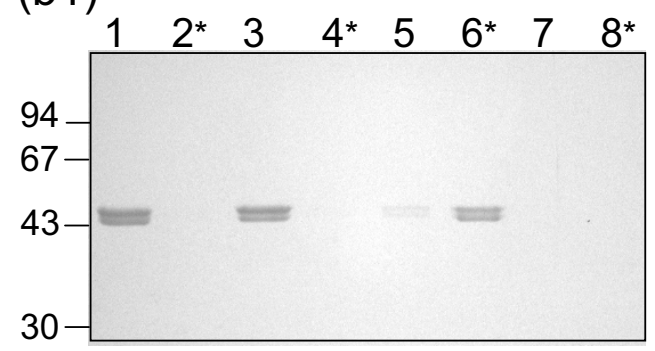

(b2)

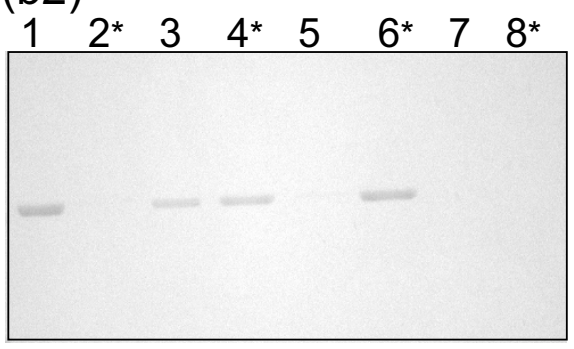

\section{Figure 6}

6(a) - Binding of truncated rSIpA proteins to isolated native cell walls of $L$. brevis ATCC 8287. Full-length rSlpA (lanes I-4), rSlpA I-145 $_{\text {(lanes 5-8), rSlpA }}$-189 (lanes 9-12), rSlpA ${ }_{190-435}$ (lanes 13-16) and rSlpA $167-435$ (lanes 17-20) were incubated with (lanes I-2, 5-6, 9-10, I3-14 and I7-18) or without (lanes 3-4, 7-8, II-I2, I5-16 and I9-20) cell walls (CWF), and the pellets and supernatants $\left(^{*}\right)$ recovered by centrifugation were analyzed by SDS-PAGE. Lanes 2 I-22, CWF incubated alone; *, supernatant. Numbers on the left indicate molecular weights in kilodaltons. 6(b) \&\#82I I Effect of treatment of cell walls with TCA at +4\&\#I76C (b ) or at +37\&\#I76C (b2) on the binding of rSlpA. Full length rSlpA was incubated with native CWF (lanes I-2) or with CWF treated with 5\% TCA (lanes 3-4) and the pellets and supernatants (*) were analyzed by SDS-PAGE. Lanes 5-6, full-length rSlpA incubated alone, lanes 7-8, TCA-treated CWF incubated alone; *, supernatant. Numbers on the left indicate molecular weights in kilodaltons.

than teichoic acid or lipoteichoic acid in the interaction between SlpA and the cell wall, as the purification process of the CWF used efficiently removed LTAs, and the extraction of CWF with TCA at $+4^{\circ} \mathrm{C}$ to remove teichoic acids had no effect on the binding of SlpA.

The chemical nature of the cell wall component interacting with the S-layer protein has been determined in Geobacillus stearothermophilus strains [47-49], in Lysinibacillus sphaericus [50] and in Aneurinibacillus thermoaerophilus [6]. In G. stearothermophilus and L. sphaericus S-layers, which possess SLH-domains, the component is a pyruvylated
GlcNac and GalNac-containing polysaccharide not groupable as a teichoic or lipoteichoic acid. In other G. stearothermophilus strains the component is a negatively charged mannuronic acid-containing cell wall polymer, and in $A$. thermoaerophilus the cell wall receptor is a neutral biantennary oligosaccharide.

The secondary cell wall polymers of lactobacilli are poorly characterized. The detailed structure of a wall polysaccharide of $L$. casei has been determined [51], but no precise structures for polysaccharides of $L$. brevis strains are available at present. In early studies, the cell walls of L. buchneri 


$\begin{array}{ll}\text { SlpC } & 60 \\ \text { Q03NT3 } & 60 \\ \text { SlpA } & 60 \\ \text { SlpB } & 60 \\ \text { SlpD } & 53 \\ \text { Q03P39 } & 53\end{array}$

$\begin{array}{ll}\text { SlpC } & 150 \\ \text { Q03NT3 } & 150 \\ \text { SlpA } & 149 \\ \text { SlpB } & 155 \\ \text { SlpD } & 150 \\ \text { Q03P39 } & 150\end{array}$

\begin{abstract}
YFRAYRVAKTTRGTVYYKMVSMDGKYRGYVYGGRSV-----KAFAGGIKKAAT 107 YFRAYRVAKTTRGTVYYKMVSMDGKYRGYVYGGRSV-----KAFAGGIKKAAT 107 YFRAYGVKT TNRGSVYYRVVTMDGKYRGYVYGGKSD-----TAFAGGIKSAET 107 NFRAYRVAKTNRGSIYYKVVSYNKAYRGWVYGGKSD-----TAFAGGLTSYDT 107 VLRGYKVAKLSNKSYYMKVVS FDGRYRGYIYVGKKNPVNNFKKVGGGLTYLST 105 VLHGYKVAKISSNKSYYMMKVVS F DRYRGYIYVGKKNPVNNFKKVGGGLTYLST 105

KAVTGWXTIXGXXYYFXXNG

KAVTGWQTIDGKWYYFDXNG

KAVTGWXTIXGXXYYFXXNG

KAVTGWQTIDGKWYYFDXNG
\end{abstract}

\begin{abstract}
TYANDALVVTDAARKTREGSLYYYVT--DAAHPEVNGWVYAKGLTTTKPTTDN 200 TYANDALVVTDAARKTREGSLYYYVT--DAAHPEVNGWVYAKGLTTTKPTTD- 199 VAKDTKFTVDQAATKTREGSLYYHVT--ATNGSG $\overline{\text { ISGWIYAGKGFSTTATGTQ }} 199$ AYKDATFSVDKVGTRTREGDTWVHVVNQNTADTKADGWILLSNLTQTNAFNE- 206 DYKGHKLVASKAAMNDMDGQKWLYVS-DVTEPTNASGWVLASQLTDYVAPKAP 201 DYKGHKLVASKAAMNDMDGQKWLYVVS-DVTEPTNA SGWVLASQLTDYVAPKAP 201

KAVTGWXTIXGXXYYFXXNG KAVTGWQTIDGKWYYFDXNG

KAVTGWXTIXGXXYYFXXNG KAVTGWQTIDGKWYYFDXNG
\end{abstract}

\section{Figure 7}

Similarity of the $\mathbf{N}$-terminal regions of $L$. brevis $\mathbf{S}$-layer proteins with carbohydrate binding motifs. The motifs were determined by Wren [45] and von Eichel-Streiber et al [44]. In the consensus sequences upper case letters indicate highly conserved residues [44] or residues with an identity of $50 \%$ or higher [45]. X, variable residue. A broken underline indicates potential carbohydrate-binding motifs at different locations: YFRAYG of SlpA corresponds to YFDxNG of the consensus sequence of Ref [44]; KAYRGW of SIpB corresponds to KAVTGW of the consensus sequences of References [44] and [45]; LSNKSYY of SlpD and Q03P39 corresponds to IDGkwYY of the consensus sequence of Ref [44].

[52] and L. brevis ATCC 8287 [53] were shown to contain neutral polysaccharides, which were suggested to be involved in the anchoring of the S-layer protein to the cell wall through hydrogen bonding [54,55]. These results are in agreement with the data presented in this study, which suggest a non-teichoic acid polysaccharide, either neutral or anionic, involved in the cell wall binding of SlpA, but the detailed structure of this polysaccharide remains to be elucidated.

Interestingly, despite the fact that polysaccharides rather than (lipo)teichoic acids of $L$. brevis ATCC 8287 are involved in the cell wall binding of SlpA, the C-terminal cell wall binding region of the S-layer protein CbsA of $L$. crispatus JCM 5810 bound to GHCl-treated L. brevis ATCC 8287 cells [15]. Using the same experimental design we showed that rSlpA and its cell wall binding fragment $\mathrm{rSlpA}_{1-145}$ bind to LiCl-treated L. acidophilus ATCC 4356 cells. The interaction between the S-layer protein and the secondary cell wall component is supposed to be lectinlike and highly specific [56], and in artificial experimental procedures the lack of a specific interaction between two complementary surfaces may be masked by unspecific charge interactions with lower affinity. To obtain information about specific interactions, competition experiments with fragments of $S_{A^{\prime}}$ CbsA and SlpA and the corresponding bacterial strains, or direct determinations of the $\mathrm{K}_{\mathrm{D}}$ values of the interactions, e. g. by surface plasmon resonance studies, are needed.

Amino acid sequence analysis of the L. brevis S-layer proteins revealed motifs with similarity to repeated C-terminal carbohydrate binding sequences detected in clostridial toxins, streptococcal glucosyltransferases and the S-layer proteins of L. acidophilus group organisms [14,44,45]. These motifs are supposed to play a general role in protein-carbohydrate interactions by acting as initial attachment sites and thus enabling the specific interactions to occur [44] and may thus be partly responsible for the observed positive cross-binding results between SlpA and L. acidophilus ATCC 4356 cells, and between the cell wall binding domain of CbsA and L. brevis ATCC 8287 cells 
(see above). The sequences of the potential L. brevis carbohydrate-binding motifs deviated to some extent from the consensus sequences determined for clostridial toxins and streptococcal transferases $[44,45]$. The divergence of the sequences in distantly related organisms and different macromolecular structures is apparently allowed as long as the basic function of the motif, bringing the interacting partners to initial contact, is preserved.

The self-assembly domain of SlpA was shown to comprise residues $179-435$ in mature SlpA, as truncated proteins encompassing this region were able to form a periodic structure indistinguishable from that formed by full length SlpA, as detected by electron microscopy. The length of the truncated protein was critical, since $\mathrm{rSlpA}_{167-}$ ${ }_{435}$ and $\mathrm{rSlpA}_{149-435}$ as well as $\mathrm{N}$-terminal truncations shorter than $\mathrm{rSlpA}_{179-435}$ were unable to form regular lattices. Apparently, the region, or part of the region, encompassing amino acids 149-178 disturbs the lattice formation of the truncated proteins either by steric hindrance and/or by preventing the acquisition of a native conformation. Trypsin degradation experiments revealed two protease resistant peptides encompassing residues 190-423 and 209-423 in mature SlpA supporting the hypothesis about a morphologically separate, compact Cterminal unit, which most probably corresponds to the round, periodically arranged structures seen in electron microscope pictures of self-assembly products of SlpA (Fig. 4). Similar trypsin degradation experiments with whole L. brevis cells resulted in identical fragments but at a very low efficiency (data not shown), indicating poor accessibility of the enzyme to the N-terminal domain through the pores in the S-layer, and further supporting the presumption about a protease sensitive, more flexible $\mathrm{N}$-terminal domain shielded from the environment beneath the C-terminal self-assembly domain. A proteaseresistant, surface-located self-assembly domain has also been observed in the N-terminal part of the S-layer protein $S_{A}$ of L. acidophilus ATCC 4356 [14]. The results of the present study are supported by the report of Hynönen et al [18], in which an antiserum specific for the recombinant peptide $\mathrm{SlpA}_{66-215}$, originating from the cell wall binding region, was not able to recognize polymerized SlpA on Lactobacillus brevis ATCC 8287 cells. In the same report, whole S-layered L. brevis ATCC 8287 cells as well as the Nterminal part of SlpA, residues 66-146 of mature SlpA in minimum, were shown to bind to immobilized fibronectin. Fibronectin is highly glycosylated, and the binding of fibronectin to a region of SlpA shielded beneath the C-terminal domain may be explained by an interaction between the protruding oligosaccharide moieties of fibronectin and the identified N-terminal carbohydrate binding sequences of SlpA. In this respect the identification of human blood group A-trisaccharide as the receptor for the S-layer protein of a human L. brevis isolate [57] is of interest, especially considering that the nine $\mathrm{N}$-terminal amino acids of the S-layer protein of this strain were identical with the N-terminus of SlpA.

\section{Conclusion}

In this work SlpA of $L$. brevis ATCC 8287 was shown to be a two-modular protein in which the domains responsible for the self-assembly (C-terminal) and cell wall binding ( $\mathrm{N}$-terminal) are located in a reverse order compared to those in all other Lactobacillus S-layer proteins characterized thus far, reflecting the unrelatedness of SlpA with previously characterized Lactobacillus S-layer proteins. The study confirms the role of conserved, repeated, general carbohydrate binding sequences in the cell wall binding domains of Lactobacillus S-layer proteins, but in contrast to the Lactobacillus acidophilus-group organisms, the specific cell wall component interacting with the S-layer protein in L. brevis ATCC 8287 was shown to be other than (lipo)teichoic acid. As SlpA is a potential tool for mucosal immunization, the data presented in this study forms a basis for further studies concerning vaccine development. The mapping of surface exposed residues in the selfassembly domain of SlpA is currently in progress.

\section{Authors' contributions}

SÅJ and UH performed the experiments (excluding electron microscopy, N-terminal sequencing and peptide mass mapping), analyzed the results, carried out the sequence analyses and prepared the manuscript. NI carried out electron microscopy, DP determined the lattice constants and performed the statistical analysis, UBS coordinated the EM studies, AP participated in the design and coordination of the study and helped to draft the manuscript. All authors read and approved the final manuscript.

\section{Additional material}

\section{Additional file 1}

Multiple amino acid sequence alignment of the $\mathrm{L}$. brevis S-layer proteins. ClustalW - alignment of the predicted mature forms of SlpA, SlpB, SlpC, SlpD, Q03NT3 and Q03P39 proteins. Asterisks, colons and dots indicate identical, strongly similar and weakly similar amino acids, respectively. A primary consensus sequence is shown below the alignment. Click here for file

[http://www.biomedcentral.com/content/supplementary/14712180-8-165-S1.pdf]

\section{Acknowledgements}

We thank Ilkka Palva for valuable discussions and critical reading of the manuscript, Esa Pohjolainen, Outi Immonen and Sinikka Ahonen for skillful technical assistance and Nisse Kalkkinen for amino acid sequencing and mass mapping. 
This work was supported by the FP6 EC-STREP project NAS-SAP 13523. The work was performed in the Centre of Excellence on Microbial Food Safety Research, Academy of Finland.

\section{References}

I. Sará M, Sleytr UB: S-layer proteins. J Bacteriol 2000, I 82:859-868.

2. Sleytr U, Messner P: Crystalline surface layers in procaryotes. Bacteriol 1988, I 70:2891-2897.

3. Lupas A, Engelhardt H, Peters J, Santarius U, Volker S, Baumeister W: Domain structure of the Acetogenium kivui surface layer revealed by electron crystallography and sequence analysis. J Bacteriol 1994, I 76: I224-I233.

4. Mesnage S, Fontaine T, Mignot T, Delepierre M, Mock M, Fouet A Bacterial SLH domain proteins are non-covalently anchored to the cell surface via a conserved mechanism involving wall polysaccharide pyruvylation. EMBO / 2000, 19:4473-4484.

5. Schäffer C, Messner P: The structure of secondary cell wall polymers: how Gram-positive bacteria stick their cell walls together. Microbiology 2005, I 5 I:643-65 I.

6. Steindl C, Schäffer C, Wugeditsch T, Graninger M, Matecko I, Müller $N$, Messner P: The first biantennary bacterial secondary cell wall polymer and its influence on S-layer glycoprotein assembly. Biochem J 2002, 368:483-494.

7. Åvall-Jääskeläinen S, Palva A: Lactobacillus surface layers and their applications. FEMS Microbiol Rev 2005, 29(3):5 I I-529.

8. Candela T, Mignot T, Hagnerelle X, Haustant M, Fouet A: Genetic analysis of Bacillus anthracis Sap S-layer protein crystallization domain. Microbiology 2005, I 5 I: | 485- | 490.

9. Huber C, Ilk N, Rüntzler D, Egelseer EM, Weigert S, Sleytr UB, Sára $M$ : The three S-layer-like homology motifs of the S-layer protein SbpA of Bacillus sphaericus CCM 2 I I 7 are not sufficient for binding to the pyruvylated secondary cell wall polymer. Mol Microbiol 2005, 55:197-205.

10. Jarosch M, Egelseer EM, Huber C, Moll D, Mattanovich D, Sleytr UB, Sára M: Analysis of the structure-function relationship of the S-layer protein SbsC of Bacillus stearothermophilus ATCC I 2980 by producing truncated forms. Microbiology 200I, | 47:1353-1363.

II. Rüntzler D, Huber C, Moll D, Köhler G, Sára M: Biophysical characterization of the entire bacterial surface layer protein SbsB and its two distinct functional domains. J Biol Chem 2004, 279:5207-52I5.

12. Johnson JL, Phelps CF, Cummins CS, London J, Gasser F: Taxonomy of the Lactobacillus acidophilus group. Int J Syst Bacteriol 1980, 30:53-68.

13. Jakava-Viljanen M, Åvall-Jääskeläinen S, Messner P, Sleytr UB, Palva A: Isolation of three new surface layer protein genes (slp) from Lactobacillus brevis ATCC 14869 and characterization of the change in their expression under aerated and anaerobic conditions. J Bacteriol 2002, 184:6786-6795.

14. Smit E, Oling F, Demel R, Martinez B, Pouwels PH: The S-layer protein of Lactobacillus acidophilus ATCC 4356: Identification and characterization of domains responsible for S-protein assembly and cell wall binding. I Mol Biol 200I, 305:245-257.

15. Antikainen J, Anton L, Sillanpää J, Korhonen TK: Domains in the Slayer protein CbsA of Lactobacillus crispatus involved in adherence to collagens, laminin and lipoteichoic acids and in self-assembly. Mol Microbiol 2002, 46(2):38I-394.

16. Vidgren G, Palva I, Pakkanen R, Lounatmaa K, Palva A: S-layer protein gene of Lactobacillus brevis: cloning by polymerase chain reaction and determination of the nucleotide sequence. J Bacteriol 1992, I 74:7419-7427.

17. Åvall-Jääskeläinen S, Kylä-Nikkilä K, Kahala M, Miikkulainen-Lahti T, Palva A: Surface display of foreign epitopes on the Lactobacillus brevis S-layer. Appl Environ Microbiol 2002, 68:5943-595I.

18. Hynönen U, Westerlund-Wikström B, Palva A, Korhonen TK: Identification by flagellum display of an epithelial cell- and fibronectin-binding function in the SIpA surface protein of Lactobacillus brevis. J Bacteriol 2002, I 84:3360-3367.

19. Axelsson L: Lactic acid bacteria: Classification and physiology. In Lactic acid bacteria: microbiology and functional aspects Edited by Salminen S, von Wright A. New York: Marcel Dekker Inc; 1998: I-73.

20. Rönkä E, Malinen E, Saarela M, Rinta-Koski M, Aarnikunnas J, Palva A Probiotic and milk technological properties of Lactobacillus brevis. Int J Food Microbiol 2003, 83:63-74.
21. Sleytr UB, Huber C, Ilk N, Pum D, Schuster B, Egelseer EM: S-layers as a tool kit for nanobiotechnological applications. FEMS Microbiol Lett 2007, 267:131-144.

22. Sleytr UB, Egelseer EM, Ilk N, Pum D, Schuster B: S-layers as a basic building block in a molecular construction kit. FEBS Journal 2007, 274:323-334.

23. Studier FW: Use of bacteriophage T7 lysozyme to improve an inducible T7 expression system. J Mol Biol I991, 2 19:37-44.

24. Sambrook J, Russell DW: Molecular cloning: a laboratory manual 3rd edition. New York: Cold Spring Harbor Laboratory Press; 200I

25. Sanger F, Nicklen S, Coulson AR: DNA sequencing with chainterminating inhibitors. Proc Natl Aca Sci USA 1977, 74:5463-5467.

26. Laemmli UK: Cleavage of structural proteins during the assembly of the head of bacteriophage T4. Nature 1970 , 227:680-685

27. Kalkkinen N, Tilgmann C: A gas-pulsed-liquid-phase sequencer constructed from a Beckman 890D instrument by using Applied Biosystems delivery and cartridge bloks. J Protein Chem 1988, 7:242-243.

28. Nyman TA, Matikainen S, Saraneva T, Julkunen I, Kalkkinen N: Proteome analysis reveals ubiquitin-conjugating enzymes to be a new family of interferon-alpha-regulated genes. Eur J Biochem 2000, 267:4011-4019.

29. Pum D, Sára M, Sleytr UB: Structure, surface charge and selfassembly of the S-layer lattice from Bacillus coagulans E3866. I Bacteriol 1989, I71:5296-5303.

30. Messner P, Pum D, Sleytr UB: Characterization of the ultrastructure and the self-assembly of the surface layer of Bacillus stearothermophilus strain NRS 2004/3a. J Ultrastruct Mol Struct Res 1986, 97:73-88.

31. Amos LA, Henderson R, Unwin PN: Three-dimensional structure determination by electron microscopy of two-dimensional crystals. Prog Biophys Mol Biol 1982, 39:183-23I.

32. Ames BN, Dubin DT: The role of polyamines in the neutralization of bacteriophage deoxyribonucleic acid. J Biol Chem I960, 235:769-775.

33. ProtParam [http://us.expasy.org/tools/protparam.html]

34. Kyte J, Doolittle R: A simple method for displaying the hydropathic character of a protein. J Mol Biol 1982, I 57: I05-I 32.

35. ProtScale [http://www.expasy.org/tools/protscale.html]

36. REPRO [http://ibivu.cs.vu.nl/programs/reprowww/]

37. George RA, Heringa J: The REPRO server: finding protein internal sequence repeats through the web. Trends Biochem Sci 2000, 25:515-517.

38. ClustalW

npsa automat.pl?page=npsa clustalw.html

39. SIM [http://au.expasy.org/tools/sim-prot.html]

40. BLAST

geblast.cgi?gi= | 9987]

41. Makarova K, Slesarev A, Wolf Y, Sorokin A, Mirkin B, Koonin E, Pavlov A, Pavlova N, Karamychev V, Polouchine N, Shakhova V, Grigoriev I, Lou Y, Rohksar D, Lucas S, Huang K, Goodstein DM, Hawkins T, Plengvidhya V, Welker D, Hughes J, Goh Y, Benson A, Baldwin K, Lee JH, Diaz-Muniz I, Dosti B, Smeianov V, Wechter W, Barabote R, Lorca G, Altermann E, Barrangou R, Ganesan B, Xie Y, Rawsthorne H, Tamir D, Parker C, Breidt F, Broadbent J, Hutkins R, O'Sullivan D, Steele J, Unlu G, Saier M, Klaenhammer T, Richardson P, Kozyavkin S, Weimer B, Mills D: Comparative genomics of the lactic acid bacteria. Proc Natl Acad Sci USA 2006, I 03: I56 I I-I56I6.

42. Sillanpää J, Martínez B, Antikainen J, Toba T, Kalkkinen N, Tankka S, Lounatmaa K, Keränen J, Höök M. Westerlund-Wikström B, Pouwels $\mathrm{PH}$, Korhonen TK: Characterization of the collagen-binding $\mathbf{S}$ layer protein CbsA of Lactobacillus crispatus. J Bacteriol 2000, I 82:6440-6450.

43. Hancock IC, Poxton IR: Bacterial cell surface techniques New York: John Wiley \& Sons Inc; 1988.

44. von Eichel-Streiber C, Sauerborn M, Kuramitsu HK: Evidence for a modular structure of the homologous repetitive $C$-terminal carbohydrate-binding sites of Clostridium difficile toxins and Streptococcus mutans glucosyltransferases. J Bacteriol 1992, I 74:6707-6710

45. Wren BW: A family of clostridial and streptococcal ligandbinding proteins with conserved C-terminal repeat sequences. Mol Microbiol I991, 5:797-803. 
46. Smit E, Pouwels $\mathrm{PH}$ : One repeat of the cell wall binding domain is sufficient for anchoring the Lactobacillus acidophilus surface layer protein. J Bacteriol 2002, I 84:4617-46I9.

47. Egelseer EM, Leitner K, Jarosch M, Hotzy C, Zayni S, Sleytr UB, Sára M: The S-layer proteins of two Bacillus stearothermophilus wild-type strains are bound via their $\mathbf{N}$-terminal region to a secondary cell wall polymer of identical chemical composition. J Bacteriol 1998, I80:|488-|495.

48. Ries W, Hotzy C, Schocher I, Sleytr UB, Sára M: Evidence that the $\mathbf{N}$-terminal part of the S-layer protein from Bacillus stearothermophilus PV72/p2 recognizes a secondary cell wall polymer. J Bacteriol 1997, 179:3892-3898.

49. Schäffer C, Kählig H, Christian R, Schulz G, Zayni S, Messner P: The diacetamidodideoxyuronic-acid-containing glycan chain of Bacillus stearothermophilus NRS 2004/3a represents the secondary cell-wall polymer of wild-type B. stearothermophilus strains. Microbiology 1999, I45:1575-1583.

50. Ilk N, Kosma P, Puchberger M, Egelseer EM, Mayer HF, Sleytr UB, Sára $M$ : Structural and functional analyses of the secondary cell wall polymer of Bacillus sphaericus CCM 2177 that serves as an S-layer specific anchor. J Bacteriol 1999, I 81:7643-7646.

5I. Nagaoka M, Muto M, Nomoto K, Matuzaki T, Watanabe T, Yokokura T: Structure of polysaccharide-peptidoglycan complex from the cell wall of Lactobacillus casei YIT90I8. J Biochem 1990, I 08:568-57I.

52. Masuda $\mathrm{K}$, Kawata $\mathrm{T}$ : Characterization of a regular array in the wall of Lactobacillus buchneri and its reattachment to the other wall components. J Gen Microbiol 198I, I 24:8I-90.

53. Shimohashi $H$, Kodaira S, Suegara N: Grouping antigens of four Lactobacillus species and their characteristics. Jpn J Microbiol I976, 20(5):405-4I3.

54. Masuda K, Kawata T: Reassembly of a regularly arranged protein in the cell wall of Lactobacillus buchneri and its reattachment to cell walls: chemical modification studies. Microbiol Immunol 1985, 29:927-938.

55. Masuda K, Kawata T: Reassembly of the regularly arranged subunits in the cell wall of Lactobacillus brevis and their reattachment to cell walls. Microbiol Immunol 1980, 24:299-308.

56. Sará M: Conserved anchoring mechanisms between crystalline cell surface $S$-layer proteins and secondary cell wall polymers in Gram-positive bacteria. Trends Microbiol 200 I, 9:47-49.

57. Uchida H, Kinoshita H, Kawai Y, Kitazawa H, Miura K, Shiiba K, Hori A, Kimura K, Taketomo N, Oda M, Yajima T, Saito T: Lactobacilli binding human A-antigen expressed in intestinal mucosa. Res Microbiol 2006, I 57:659-665.

58. Woodcock D, Crowther P, Doherty J, Jefferson S, De Cruz E, NoyerWeidner M, Smith S, Michael M, Graham M: Quantitative evaluation of Escherichia coli host strains for tolerance to cytosine methylation in plasmid and phage recombinants. Nucleic Acids Res 1989, I 7:3469-3478.
Publish with Bio Med Central and every scientist can read your work free of charge

"BioMed Central will be the most significant development for disseminating the results of biomedical research in our lifetime. "

Sir Paul Nurse, Cancer Research UK

Your research papers will be:

- available free of charge to the entire biomedical community

- peer reviewed and published immediately upon acceptance

- cited in PubMed and archived on PubMed Central

- yours - you keep the copyright
BioMedcentral 